\title{
PERENCANAAN KELUARGA DAN FERTILITAS SUKU BAJO DI ERA PERUBAHAN (STUDI KASUS: SUKU BAJO DI PERKAMPUNGAN MOLA KECAMATAN WANGI-WANGI SELATAN KABUPATEN WAKATOBI)
}

\author{
Subardjan \\ Masuk: 01022017 / Diterima: 01042017 / Dipublikasi: 30062017 \\ (c) 2017Fakultas Hukum dan IImu Sosial UNDIKSHA dan IGI
}

\begin{abstract}
The purpose of this research was to know the family planning and fertility Bajo ethnic with focus on: (1) wife husband views to family planning, (2) identify social conditions, economy, demography and culture in its bearing with family planning, (3) analyzing KB contraceptive device purpose and fertility. Analyzed by quantity statistic technique (crosstab) and qualitative analysis technique. Result of this research showed that: (1) point of family on wife husband couple of Bajo ethnic at changing era was value of "extended family"; (2) social aspects, economy, demography, and culture were prescriptive aspects families in "changing era" in this case total of child desirable and preference to man stills high. (3) from condition of point (1 and 2) causing lush age of woman (15-49) years old of Bajo ethnic majority didn"t use KB contraceptive device. So begets fertility in this case total of average born life child (ALH) and child ls still live (AMH) tended higher.
\end{abstract}

Key words: Family Planning, Fertility, Bajo Ethnic, Transition

Abstrak Penelitian ini bertujuan untuk mengungkap perencanaan keluarga dan fertilitas suku Bajo dengan fokus: (1) pandangan suami-istri terhadap perencanaan keluarga, (2) mengidentifikasi kondisi sosial, ekonomi, demografi dan budaya dalam kaitannya dengan perencanaan keluarga, (3) menganalisis penggunaan alat kontrasepsi KB dan fertilitas. Analisis dilakukan dengan tekhnik statistik kuantitaif (crosstab) dan tekhnik analisis kualitatif (Miller dan Huberman). Hasil penelitian menunjukkan bahwa : (1) nilai keluarga yang berlaku pada pasangan suami-istri suku Bajo di era perubahan adalah nilai "keluarga besar"; (2) aspek- aspek sosial, ekonomi, demografi, dan budaya merupakan aspek-aspek yang menentukan ukuran keluarga di "era perubahan" dalam hal ini jumlah anak yang diinginkan dan preferensi terhadap anak laki-laki yang masih tinggi. (3) dari kondisi tersebut (1 dan 2) sehingga menyebabkan wanita usia subur (15-49) tahun suku Bajo mayoritas tidak menggunakan alat kontrasepsi KB. Dengan demikian, mengakibatkan fertilitas dalam hal ini jumlah rata-rata Anak Lahir Hidup (ALH) dan Anak Masih Hidup (AMH) cenderung lebih tinggi.

Kata-kata kunci : Perencanaan Keluarga, Fertilitas, Suku Bajo, Era Perubahan

\section{Pendahuluan}

Seiring dengan perjalanan

waktu dengan perubahan struktur

Subardjan

STKIP Pelita Buton

Sulawesi Tenggara

bayubarian@yahoo.co.id pemerintahan ke otonomi daerah, segala kewenangan di limpahkan ke daerah. Harapan pemerintah pusat adalah dengan pelimpahan kewenangan tersebut pemerintah daerah dapat melanjutkan program yang ada dengan konsistensi pada 
penurunan TFR. Namun harapan itu tidak sesuai dengan kenyataan yang ada, pemerintah daerah justru terkosentrasi pada pertumbuhan ekonomi semata sementara pembangunan kependudukan seakan terlupakan. Kondisi ini bukan hanya terjadi di satu daerah namun hampir di setiap daerah. Hal ini dapat terlihat TFR Indonesia mengalami peningkatan dari 2,26 pada SUPAS 2005 menjadi 2,6 pada SDKI 2007 namun pada SP 2010 TFR Indonesia stagnan pada angka 2,6 (BPS, 2010). Sementara itu pertumbuhan penduduk 1,49\% pada tahun 2010 pertahun. Jika memperhatikan penurunan yang dicapai sebelumnya maka dapat dikatakan bahwa perlu ada evaluasi kebijakan yang terkait dengan penurunan TFR.

Kabupaten Wakatobi adalah salah satu kabupaten yang terletak di Propinsi Sulawesi Tenggara memiliki jumlah penduduk sebesar 87.793 jiwa pada SP 2000 menjadi 10.3422 pada SP 2010, dengan laju pertumbuhan $1,92 \%$ pertahun pada SP 2010. Sementara TFR kabupaten Wakatobi pada SP 2010 adalah 3,1 dan rata- rata $\mathrm{ALH}$ kabupaten Wakatobi 3,098 (BPS Kab. Wakatobi 2010). Data ini jika di banding dengan TFR nasional pun masih jauh melampaui. Kondisi ini tidak terlepas dari produk faktorfaktor yang mempengaruhi tingkat fertilitas penduduk setempat dengan latar belakang suku, budaya, agama, termasuk faktor demografi yang lain. Salah satu suku bangsa yang terdapat di Kabupaten Wakatobi adalah suku Bajo dimana suku bangsa ini mendiami wilayah pesisir Kecamatan Wangi-Wangi Selatan. Suku Bajo biasa juga disebut suku Sama atau Bajau yaitu pelaut tangguh. Pada umumnya mereka memilih hidup atau bermukim di lautan baik secara nomaden maupun menetap dengan membangun rumah-rumah tiang di atas lautan yang terpisah dari daratan. Menurut Mahmud (1980) suku Bajo diidentikkan dengan suku pelaut yang memiliki banyak anak.

Suku Bajo di perkampungan Mola adalah suku bangsa yang berbeda dengan suku Bajo pada umumnya. Ada beberapa hal yang membedakan suku Bajo di perkampungan Mola dengan suku Bajo yang lain; pertama, dengan adanya perubahan sistem pemerintahan dari sentralisasi ke desentralisasi (otonomi), Wakatobi mengalami pemekaran menjadi kabupaten pada tahun 2002 yang menjadikan permukiman suku Bajo di perkampungan Mola ke dalam wilayah administratif ibu kota kabupaten Wakatobi. Tentunya hal ini sedikit memudahkan mereka menjangkau fasilitas publik seperti, fasilitas pendidikan, kesehatan, perekonomian dan lain sebagainya yang diharapkan dapat meningkatkan status sosial, ekonomi, tingkat kesehatan, dan lain sebagainya.

Kedua, Suku Bajo di perkampungan Mola merupakan suku Bajo yang sebagian besar sudah mendarat dan membaur dengan masyarakat yang ada di darat. Dengan demikian dari dua hal tersebut dapat diasumsikan bahwa 
dengan perubahan kearah moderenisasi yaitu dengan peningkatan status sosial, ekonomi, dan keterbukaan dengan masyarakat di darat seyogyanya dapat merubah pola pikir mereka diantaranya adalah perencanaan keluarga dan fertilitas.

Berdasarkan hasil observasi awal yang dilakukan peneliti yaitu dengan wawancara dengan beberapa tokoh suku Bajo, peneliti memperoleh data bahwa pada umumnya suku Bajo di perkampungan Mola menginginkan anak lebih dari 2 orang. Adapun alasan klasik yang mendasari mereka adalah sebagai berikut: (1) adanya pandangan dari mereka bahwa anak merupakan aset masa depan bagi orang tua terutama anak laki-laki, (2) adanya kekhawatiran akan adanya serangan wabah penyakit yang menimpa anak, sehingga jika satu atau dua yang meninggal masih ada anak yang lain serta (3) banyak anak banyak rezeki. Menurut Becker (1995) jika dilihat dari aspek permintaan bahwa harga anak lebih besar pengaruhnya dibandingkan dengan income. Disamping itu nilai anak dipandang aspek produksi. Berdasarkan aspek produksi, utilitas anak berbeda dengan aspek konsumsi. Karena utilitas anak lebih dilihat dari aspek kuantitas dan bukan kualitas. Artinya semakin memandang bahwa anak adalah merupakan modal maka permintaan akan anak menjadi meningkat. Dengan demikian jika permintaan akan anak tinggi diduga tingkat fertilitas dalam hal ini Total Fertility Rate (TFR) ikut meningkat.

Tabel 1.

\begin{tabular}{clcc}
\multicolumn{3}{c}{ Jumlah Anak Lahir Hidup Perkecamatan di Kabupaten Wakatobi Tahun 2010} \\
\hline No & Kecamatan & Anak Lahir Hidup & $\begin{array}{c}\text { Jumlah Penduduk } \\
\text { Usia 0-5 Tahun }\end{array}$ \\
\hline 1 & Wangi-wangi & 503 & 2.623 \\
2 & Wangi-wangi Selatan & 482 & 3.277 \\
3 & Kaledupa & 151 & 592 \\
4 & Kaledupa Selatan & 112 & 506 \\
5 & Tomia & 156 & 773 \\
6 & Tomia Timur & 162 & 942 \\
7 & Binongko & 171 & 768 \\
8 & Togo Binongko & 115 & 481 \\
& Jumlah & 1852 & 9962 \\
\hline
\end{tabular}

Sumber : Dinas Kesehatan Kabupaten Wakatobi, 2010

Data kuantitatif menunjukkan di kecamatan Wangi-Wangi Selatan jumlah anak Lahir Hidup (ALH) mencapai 482 dengan jumlah penduduk 24.534 jiwa. Sementara jumlah anak pada kelompok umur 05 menunjukkan 3.277 jiwa. Angka ini merupkan angka yang tertinggi jika di bandingkan dengan wilayah kecamatan lain.

Data ini menunjukkan bahwa di kecamatan Wangi-Wangi Selatan (daerah penelitian) diduga memiliki tingkat fertilitas yang tinggi. Data 
lain yang menjadi acuan adalah adanya tren peningkatan Pasangan Usia Subur (PUS). Pasangan Usia Subur (PUS) di Kecamatan WangiWangi Selatan Kabupaten Wakatobi pada tahun 2007 menunjukkan angka 3.100 , meningkat menjadi
4.241 pada tahun 2008, selanjutnya meningkat lagi menjadi 5.015 pada tahun 2010. Fenomena ini merupakan peningkatan yang paling tinggi jika di bandingkan dengan kecamatan lain yang ada di Kabupaten Wakatobi.

Tabel 2

Jumlah Pasangan Usia Subur (PUS) Kabupaten Wakatobi Perkecamatan

\begin{tabular}{llccc}
\hline No & Kecamatan & \multicolumn{3}{c}{ Jumlah PUS } \\
\cline { 3 - 5 } & & 2007 & 2008 & 2010 \\
\hline 1 & Wangi-wangi & 3707 & 4259 & 4997 \\
2 & Wangi-wangi Selatan & 3100 & 4241 & 5015 \\
3 & Kaledupa & 1436 & 1498 & 1938 \\
4 & Kaledupa Selatan & 287 & 1511 & 2077 \\
5 & Tomia & 1740 & 1463 & 1298 \\
6 & Tomia Timur & 665 & 1802 & 1781 \\
7 & Binongko & 1835 & 1680 & 1346 \\
8 & Togo Binongko & - & 1207 & 912 \\
& $\quad$ Jumlah & 12.770 & 17.661 & 19.364 \\
\hline
\end{tabular}

Sumber : BKKBN Kabupaten Wakatobi

Menagacu pada beberapa konsep di atas jika dihubungkan dengan data yang mendeskripsikan lokasi penelitian, maka penulis tertarik untuk meneliti faktor- faktor apa yang menentukan perencanaan keluarga suku Bajo Mola dalam kaitannya dengan fertilitas dimana suku Bajo di perkampungan Mola sudah mulai mendarat. Adapun judul dari penelitian ini adalah "Perencanaan Keluarga dan Fertilitas Suku Bajo di Era Perubahan". Penelitian ini difokuskan pada masyarakat suku Bajo di perkampungan Mola Kecamatan Wangi-Wangi Selatan. Tujuan penelitian ini adalah untuk mengetahui perencanaan keluarga dan fertilitas suku Bajo. Selanjutnya tujuan penelitian ini secara rinci sebagai berikut: (1). Untuk mengetahui pandangan suami-istri terhadap perencanaan keluarga (jumlah anak ideal yang diinginkan, preferensi anak); (2) Untuk mengidentifikasi kondisi sosial (pendidikan), ekonomi (status pekerjaan, penghasilan), demografi (umur, umur kawin pertama) dan sosial budaya (upacara adat, nilai anak, mata pencaharian, pola perkawinan, religi dan kepercayaankepercayaan, sistem pengetahuan, sistem kekerabatan) dan kaitannya dengan perencanaan keluarga; (3) Untuk menganalisis penggunaan kontrasepsi KB dan fertilitas (anak lahir hidup) suku Bajo.

\section{Metode}

Pendekatan utama dalam penelitian ini adalah menggunakan metode gabungan (mix metode) yaitu kuantitatif (survey explanatory) dan kualitatif (eksplorasi parsitipatif) 
yang dilakukan dengan tekhnik wawancara mendalam dan parsitipatif. Hal ini dilakukan untuk mengungkap dan menggali informasi tentang status sosial-ekonomi, demografi, dan budaya yang berlaku pada masyarakat suku Bajo terkait dengan perencanaan keluarga dan fertilitas.

Metode survey explanatory, dilakukan dengan tujuan untuk mengindentifikasi sampel, memperoleh gambaran umum karasteristik sampel, dan sebagai kualifikasi/seleksi informan. Selain itu juga metode survey tersebut bertujuan sebagai validasi data dari informan yang dilakukan dengan cara crosscek, yaitu data yang disampaikan oleh informan dicek kembali kepada responden apakah yang disampaikan oleh informan kunci cenderung sama ataukah ada hal-hal yang baru. Terkait dengan survey, penentuan sampel dalam penelitian ini menggunakan teknik sampling meliputi: (1) area sampling ditentukan dengan tekhnik purposif dilakukan dengan pertimbangan bahwa kasus yang diteliti secara spesifik terjadi pada dua desa yaitu Desa Mola Utara dan Desa Mola Selatan, (2) responden adalah wanita usia subur umur (15-49) tahun yang ditentukan dengan tekhnik quota sampling yaitu 100 orang dengan pertimbangan bahwa sejumlah sampel tersebut dipandang sudah cukup mewakili karakteristik populasi. Dari jumlah tersebut kemudian masing-masing desa ditentukan dengan proportional random sampling, dengan menggunakan skenario perhitungan menghasilkan 31 orang terdapat di desa Mola Utara dan 69 orang di desa Mola Selatan.

Mengingat pendekatan utama adalah kualitatif, maka selanjutnya ditetapkan sebanyak 15 informan yang dianggap lebih tahu dan mudah ditemui untuk wawancara dengan kriteria berdasarkan: 1) kelompok umur, 2) tingkat pendidikan, 3) umur kawin pertama, 4) status pekerjaan, 5) pola perkawinan. Selanjutnya untuk lebih mendalami budaya yang berkaitan dengan fertilitas ditetapkan 4 (empat) tambahan informan kunci. Untuk menentukan informan kunci dalam penelitian, peneliti terlebih dahulu berkonsultasi dengan tokoh yang ada di perkampungan Mola dalam hal ini adalah kepala desa Mola Selatan dan kepala desa Mola Utara.

Dari hasil konsultasi tersebut ditetapkan 4 (empat) informan kunci yang salah satu diantaranya adalah dukun beranak "pangileh" dan yang lain adalah orang yang lebih mengetahui budaya dan sejarah suku Bajo. Langkah pertama yang dilakukan pada analisis data pada penelitian ini adalah menganalisis data kuantitatif (survey) yaitu dengan crosstab dalam bentuk presentase, dan rata-rata (mean). Variabel yang dianalisis secara kuantitatif antara lain; sosial, ekonomi dan demografi serta pengaruhnya terhadap penggunaan alat kontrasepsi KB dan fertilitas. Hasil dari analisis tersebut dijadikan sebagai dasar analisis selanjutnya (kualitatif) yaitu dengan menelusuri dari berbagai informasi dari informan. Sedangkan variabel 
budaya dianalisis secara kualitatif murni menggunakan analisis data kualitatif yang dikembangkan oleh Miler dan Huberman (1992, dalam Basrowi dan Suwandi, 2008).

\section{Hasil dan Pembahasan}

\section{Pengaruh Sosial, Ekonomi, Demografi Terhadap Perencanaan Keluarga, Penggunaan Alat Kontrasepsi dan Fertilitas}

Faktor sosial, ekonomi dan demografi termasuk budaya merupakan faktor yang dapat mempengaruhi fertilitas melalui sebelas variabel antara (Blake, 1956 dalam Mantra 2000). Disamping itu penggunaan alat kontrasepsi merupakan faktor yang secara langsung dapat mempengaruhi fertilitas. Kesebelas faktor- faktor itu masing-masing mempunyai pengaruh (nilai) positif dan negatif sendiri- sendiri terhadap fertilitas. Pengaruh dari variabel-variabel di atas terhadap masyarakat yang satu dengan yang lain berbeda-beda. Masyarakat suku Bajo merupakan masyarakat dengan latar belakang sosial, ekonomi dan demografi serta budaya yang berbeda dari masyarakat lain. Dengan perubahan pola permukiman dari laut ke daratan, suku terasing menjadi orang kota merupakan era baru (era perubahan) bagi suku Bajo yang ada di perkampungan Mola. Sesuai dengan hasil penelitian dari Suandi ,
2010, Melalui perkembangan atau kemajuan masyarakat berdampak positif terhadap perubahan status wanita. Wanita lebih banyak bekerja di luar rumah daripada bekerja domestik baik dengan maksud tambahan pendapatan maupun carier. Mereka ingin mengembangkan dirinya sehingga mereka ingin mempunyai jumlah anak yang kecil, dan tidak terus menerus dikungkung oleh urusan dapur dan anak-anak. Hal ini disebabkan karena kehidupan kota dicirikan oleh masalah perumahan dan kebutuhan hidup yang senantiasa meningkat. Keadaan kehidupan seperti ini, keluarga kecil lebih menguntungkan (kualitas anak).

Secara perlahan, suku Bajo sudah tersentuh oleh modernisasi. Hal itu dapat terlihat pada penggunaan alat-alat teknologi canggih seperti kendaraan bermotor, alat komunikasi, sampai pada alatalat elektronik canggih lainnya. Kondisi tersebut semestinya diikuti dengan peningkatan pendidikan, derajat kesehatan serta bidangbidang lain yang diharapkan dapat memperbaiki kesejahteraan termasuk fertilitas. Hal tersebut berbeda dengan harapan dan kenyataan. Pendidikan pada wanita usia subur (15-49) tahun di suku Bajo yang ada di perkampungan 
Mola, ditemukan mayoritas berpendidikan rendah. Hal ini disebabkan oleh karena di lokasi penelitian fasilitas pendidikan tertinggi hanya sampai pada tingkat Sekolah Dasar (SD).

Disamping itu tingkat kesadaran dari masyarakat suku Bajo yang masih rendah terhadap pendidikan. Sebagai akibat dari pengetahuan yang cenderung rendah tesebut, wanita usia subur (15-49) tahun suku Bajo cenderung menginginkan anak yang lebih banyak. Jumlah anak yang diinginkan wanita usia subur (15-49), pada tingkat pendidikan yang rendah cenderung tinggi sedangkan pada tingkat pendidikan yang tinggi cenderung rendah (hubungan negatif). Hal yang sama juga terlihat pada keinginan terhadap anak lakilaki dan anak perempuan. Wanita usia subur pada semua tingkat pendidikan, kecenderungan terhadap anak laki-laki lebih tinggi dibandingkan anak perempuan. Hal ini disebabkan karena pada wanita usia subur (15-49) tahun dengan tingkat pendidikan rendah, mereka cenderung tertutup dengan keadaan luar sehingga minim informasi dan pengetahuan. Sedangkan pada wanita usia subur (15-49) tahun dengan pendidikan yang tinggi, disamping memiliki pola pikir dan pemahaman yang lebih rasional, juga sangat intens berinteraksi dengan orang- orang diluar suku Bajo (bagai). Sebagai akibat dari hal tersebut, wanita usia subur (15-49) tahun dengan pendidikan rendah mayoritas tidak menggunakan alat kontrasepsi $\mathrm{KB}, \quad$ sehingga berdampak pada jumlah anak lahir hidup (ALH) dan anak masih hidup $(\mathrm{AMH})$ cenderung lebih tinggi. Kondisi ini mengindikasikan bahwa tingkat fertilitas di daerah penelitian juga tinggi.

Status pekerjaan wanita usia subur (15-49) tahun di desa Mola Utara dan Mola Selatan mayoritas berstatus tidak bekerja. Hal ini disebabkan karena tingkat pendidikan yang rendah juga pekerjaan utama yang ada di suku Bajo adalah nelayan, yang mana hanya mampu dikerjakan oleh lakilaki (suami). Sehingga para suami cenderung melarang para istri untuk bekerja. Secara umum, jumlah anak dan preferensi anak laki-laki yang diinginkan oleh wanita usia subur (15-49) yang bekerja cenderung lebih tinggi sedangkan wanita usia subur (15-49) yang tidak bekerja cenderung lebih rendah (pola hubungan positif). Hal tersebut disebabkan karena pada wanita yang bekerja rata-rata bekerja pada sektor informal, sehingga anak yang diinginkan selain sebagai tenaga kerja untuk melaut juga sebagai tenaga kerja pada sektor informal.

Selain itu pada wanita usia subur (15-49) tahun, keputusan anak merupakan keputusan bersama antara suami dan istri. Sehingga mereka tidak mempermasalahkan jumlah anak. Dengan demikian anak yang diinginkan cenderung lebih tinggi. Sedangkan pada wanita usia subur (15-49) tahun yang tidak bekerja anak yang diinginkan hanya sebagai tenaga kerja untuk melaut, 
sehingga anak yang diinginkan cenderung lebih rendah jika dibandingkan dengan wanita yang bekerja. Kondisi tersebut mengakibatkan wanita usia baik yang bekerja maupun tidak bekerja cenderung tidak menggunakan alat kontrasepsi KB. Akibatnya adalah Anak Lahir Hidup dan Anak Masih Hidup cenderung lebih tinggi.

Penghasilan wanita usia subur (15-49) tahun suku Bajo mayoritas memiliki penghasilan yang rendah. Secara umum menunjukkan jumlah anak dan preferensi anak laki-laki yang diinginkan wanita usia subur (15-49) tahun pada penghasilan rendah cenderung tinggi, sementara pada wanita usia subur (15-49) dengan penghasilan sedang cenderung rendah sedangkan pada wanita usia subur (15-49) cenderung tinggi (pola hubungan model kurva"U"). Hal ini disebabkan karena pada penghasilan rendah yang mayoritas bekerja sebagai nelayan, memiliki kualifikasi pendidikan yang rendah sehingga masih menganggap anak sebagai aset tenaga kerja. Dengan demikian jumlah anak yang diinginkan maupun preferenasi anak (laki-laki) cenderung tinggi. Sementara pada penghasilan tinggi, mayoritas bekerja sebagai pengusaha penjual ikan tuna dan teripang, yang mana masih menganggap anak sebagai aset tenaga kerja untuk mengurus usaha sehingga jumlah anak yang diingikan serta preferensi anak lebih tinggi. Sedangkan pada penghasilan sedang mayoritas bekerja sebagai PNS dengan kualifikasi pendidikan tinggi. Dengan demikian mereka lebih mempertimbangkan jumlah anak, sehingga cenderung membatasi jumlah anak yang diingikan dan preferensi anak (anak laki-laki) lebih rendah. $\mathrm{Hal}$ ini tentunya berakibat pada penggunaan alat kontrasepsi $\mathrm{KB}$. Pada wanita usia subur (15-49) tahun dengan penghasilan rendah dan tinggi cenderung tidak menggunakan alat kontrasepsi KB. Sementara pada wanita usia subur (15-49) tahun dengan penghasilan sedang cenderung menggunakan alat kontrasepsi KB. Sehingga kondisi tersebut menyebabkan perbedaan ALH dan AMH.

Wanita usia subur (15-49) tahun pada penghasilan rendah dan tinggi, ALH maupun AMH cenderung rendah sementara pada penghasilan sedang cenderung rendah. Umur wanita usia subur (15-49) tahun mayoritas berada pada kelompok umur (25-29) tahun. Secara umum menunjukkan jumlah anak yang diinginkan dan preferensi anak lakilaki yang diinginkan wanita usia subur (15-49) tahun pada umur muda cenderung lebih rendah, sedangkan wanita usia subur (1549) pada umur tua cenderung lebih tinggi (pola hubungan positif). Hal tersebut disebabkan oleh karena pada umur muda disamping ratarata memiliki pendidikan menengah juga memiliki mobilitas yang cukup tinggi, intens berinteraksi dengan orang diluar suku Bajo. Sehingga mereka lebih "up to date" akan informasi dan pengetahuan. Sedangkan wanita usia subur (1549) tahun disamping mayoiritas 
berpendidikan rendah/tidak sekolah, juga lebih banyak bekerja di dalam rumah dan cenderung tertutup dengan keadaan luar. Sehingga minim informasi dan pengetahuan. Disamping itu, wanita usia subur (15-49) tahun pada umur tua anakanak telah banyak yang bekerja sehingga orang tua telah merasakan kontribusi anak terhadap ekonomi keluarga (terutama anak laki-laki). Juga orang tua merasa kesepian karena anak-anaknya sebagian telah menikah dan tinggal di tempat lain. Hal lain yang ditemuai pada wanita usia tua adalah adanya rasa trauma terhadap kematian anak terdahulu. Dengan demikian ada kecenderungan untuk menambah anak lagi. Hal tersebut berakibat pada pemakaian alat kontrasepsi KB. Pada umur muda cenderung menggunakan alat kontrasepsi $\mathrm{KB}$ sedangkan pada umur tua cenderung tidak menggunakan alat kontrasepsi KB. Dengan demikian menyebabkan perbedaan ALH dan $\mathrm{AMH}$. Pada wanita dengan kelompok umur muda, ALH dan $\mathrm{AMH}$ cenderung lebih rendah. Sementara wanita usia subur (1549) tahun, ALH dan AMH cenderung lebih tinggi. Dengan kata lain dapat dikatakan bahwa fertilitas wanita usia subur (15-49) tahun pada kelompok umur muda cenderung tinggi, sebaliknya fertilitas wanita usia subur (15-49) tahun cenderung lebih rendah.

Usia kawin pertama wanita usia subur (15-49) tahun yang ada di desa Mola Utara dan Mola Selatan mayoritas berada pada kelompok usia kawin (16-19) tahun. Hal ini disebabkan oleh karena sering terjadinya budaya kawin lari pada kalangan suku Bajo dan budaya menjodohkan. Secara umum menunjukkan jumlah anak dan preferensi anak laki-laki yang diinginkan wanita usia subur (15-49) pada usia kawin muda ( $<16$ tahun) cenderung lebih tinggi, sedangkan wanita usia subur (15-49) pada usia perkawinan tua (24+ tahun) cenderung lebih rendah (pola hubungan negatif). Hal ini disebabkan oleh karena wanita usia subur (15-49) pada perkawinan muda belum mapan baik secara usia, pendidikan dan pola pikir sehingga tidak ada perencanaan keluarga (dalam hal ini jumlah anak) yang mantap. Sehingga yang ditemukan pada wanita usia subur (15-49) tahun dengan usia kawin muda $(<16)$ tahun keinginan terhadap jumlah anak berdasarkan riwayat keluarga terdahulu (jumlah saudara kandung). Sedangkan wanita usia subur (15-49) pada umur perkawinan (24+ tahun) rata-rata berpendidikan menengah dan tinggi. Sehingga lebih matang dalam merencanakan keluarga (jumlah anak) sehingga anak yang diinginkan cenderung lebih sedikit. Beertolak dari kondisi tersebut berakibat pada penggunaan alat kontrasepsi KB. Pada wanita usia subur (15-49) tahun dengan usia perkawinan yang muda $(<16)$ tahun cenderung tidak menggunakan alat kontrasepsi KB dengan alasan ingin menambah jumlah anak. Sedangkan wanita usia subur (15-49) tahun cenderung menggunakan alat kontrasepsi KB karena kematangan 
pengetahuan. Sehingga yang terjadi adalah perbedaan jumlah Anak Lahir Hidup (ALH) dan Anak Masih Hidup (AMH). Wanita usia subur (15-49) tahun dengan usia kawin pertama muda $(<16)$ tahun, ALH dan AMH cenderung tinggi. Sementara wanita usia subur (15-49) tahun dengan perkawinan tua (24+) tahun, ALH dan $\mathrm{AMH}$ cenderung lebih rendah. Dengan kata lain tingkat fertilitas cenderung tinggi pada wanita usia subur (15-49) tahun dengan usia kawin pertama muda, sementara tingkat fertilitas cenderung rendah pada wanita usia subur (15-49) tahun dengan usia kawin pertama yang lebih tua. Dengan demikian, secara umum dapat disimpulkan bahwa faktor sosial, ekonomi dan demografi serta penggunaan alat kontrasepsi suku Bajo di era perubahan (dimana mereka sudah mendarat) dapat menentukan fertilitas. Hal tersebut sebagai akibat dari keinginan terhadap jumlah anak yang tinggi dan preferensi anak lakilaki yang cenderung tinggi. Sehingga norma keluarga yang berlaku adalah "norma keluarga besar".

\section{Pengaruh Aspek Budaya Terhadap Perencanaan Keluarga dan Fertilitas}

$\begin{array}{rrr} & \text { Aspek budaya merupakan } \\ \text { salah satu aspek yang } & \\ \text { mempengaruhi fertilitas. Aspek }\end{array}$
budaya selalu terkait dengan nilai anak yaitu motivasi untuk memiliki anak. Di suatu masyarakat dengan kondisi budaya tertentu akan berbeda dengan masyarakat yang lain dengan budaya yang berbeda. Salah satunya adalah masyarakat suku Bajo. Dengan latar belakang budaya sebagai suku laut, mayoritas bekerja sebagai nelayan tentunya akan berbeda dengan masyakat yang tinggal di darat pekerjaan utama bukan sebagai nelayan. Namun secara khusus suku Bajo yang ada di perkampungan Mola, merupakan suku Bajo yang sedang menuju perubahan. Sebab mereka sudah bermukim di darat dan menjadi bagian dari masyarakat perkotaan. Bentuk-bentuk upacara adat pada masyarakat Bajo yang ada di desa Mola Utara dan Mola Selatan boleh dikata cukup banyak.

Namun pada penelitian ini yang sempat diidentifikasi hanya beberapa bentuk upacara saja, antara lain;

- massuro merupakan bentuk upacara adat yang dilakukan untuk memulai suatu perkawinan yang biasa di sebut "lamaran" atau "pinangan" pada masyarakat Bajo,

- duata, dilakukan jika ada salah satu diantara mereka mengalami sakit keras dan tidak lagi dapat disembuhkan dengan cara lain termasuk pengobatan medis,

- upacara bagi wanita hamil, terdapat (3-4) kali upacara yang dikenal yaitu pada usia kehamilan 40 hari, 3 bulan, 5 bulan, dan 7 bulan.

Dari beberapa bentuk upacara tersebut tidak ditemukan keterlibatan anak baik anak laki-laki maupun anak perempuan untuk kepentingan upacara. Artinya jika anak sering dilibatkan dalam upacara maka ada motivasi untuk memiliki anak untuk kepentingan 
upacara adat. Misalnya seperti di Nepal motivasi untuk memiliki anak laki-laki sangat tinggi karena hanya anak laki-laki yang dapat melakukan upacara kematian untuk orang tua serta upacara lainnya setelah orang tua meninggal. Dengan demikian upacara adat yang terjadi di Suku Bajo Mola tidak mempengaruhi keinginan terhadap jumlah anak serta fertilitas. Pada masyarakat suku Bajo yang ada di desa Mola Utara dan Mola Selatan, memiliki kepercayaan "jika memiliki anak lima orang berarti sudah menjalankan rukun Islam, jika memiliki anak enam orang telah menjalankan rukun iman". Tidak dapat dibayangkan jika masyarakat suku Bajo semua menjalankan kepercayaan tersebut. Artinya bahwa rata-rata anak yang dimiliki minimal lima orang. Setelah ditelusuri ke beberapa informan yang menjalankan kepercayaan tersebut menunjukkan rata-rata anak yang dimiliki adalah 6 orang dan mereka masih ingin menambah anak lagi. Selain kepercayaan tersebut kepercayaan pengobatan yang masih menggunakan jasa dukun. Dengan pengobatan serba tradisional, mengandalkan mantra yang ditiupkan ke segelas air lalu diminum, menyebabkan kematian anak cenderung tinggi disamping sanitasi yang buruk. Sehingga dengan kematian anak tersebut, orang tua cenderung ingin menambah anak yang lebih banyak karena adanya kekhawatiran akan kematian anak. Dengan demikian sistem kepercayaan (belief) pada masyarakat suku Bajo dapat mempengaruhi fertilitas. Sistem pengetahuan suku Bajo cenderung masih merunut pada sistem pengetahuan tradisional. Sebagai masyarakat yang mengandalkan penghasilan dari melaut (nelayan), mereka percaya bahwa kelimpahan hasil tangkapan (rezeki) tergantung pada ridhonya sang istri. Sehingga "jika ingin hasil tangkapannya berlimpah maka sebelum melaut harus terlebih dahulu berhubungan istri". Hal ini menunjukkan frekuensi hubungan seks. Jika setiap hari melaut bahkan dalam sehari dua kali melaut, tidak dapat dibayangkan frekuensi hubungan seks yang terjadi. Namun hal itu sulit untuk dibuktikan. Sebagaimana yang diungkapkan oleh Davis dan Blake bahwa salah satu di antaranya yang mempengaruhi fertilitas adalah frekuensi hubungan seks. Walaupun menurut Davis dan Blake variabel tersebut merupakan variabel yang lemah, namun minimal frekuensi hubungan seks dapat memberi peluang terjadinya kehamilan. Apalagi tidak diikuti dengan pemakaian alat kontrasepsi, maka tidak menutup kemungkinan ada peluang dari seorang wanita untuk hamil.

Mata pencaharian sebagai
nelayan, suku Bajo $\begin{array}{r}\text { sering } \\ \text { melibatkan anak-anak terutama }\end{array}$
anak laki-laki untuk melaut. Sejak
kecil anak laki-laki sudah
disosialisasikan dengan kehidupan
laut. Sehingga sejak umur (7-10)
tahun, anak laki-laki sudah sering
diajak untuk temani bapak atau
pamannya untuk mencari ikan. Jika
anak laki-laki melaut pada umur
tersebut maka mereka sudah


menjadi bagian yang dianggap mempunyai hak dan kewajiban yang sama dengan orang dewasa dalam proses produksi. Jika anak laki-laki ikut pamannya melaut, hasil tangkapan yang merupakan bagian dari anak tersebut akan dibawa pulang ke orang tuanya. Sehingga pada masyarakat suku Bajo keinginan terhadap anak diantaranya adalah karena anak dipandang sebagai faktor ekonomi. Terlebih sudah mendarat dan menjadi bagian masyarakat kota, kebutuhan cenderung meningkat sementara pekerjaan utama hanya sebagai nelayan. Dengan demikian untuk menambah penghasilan keluarga, anak sering dilibatkan sebagai faktor produksi (tenaga kerja). Sehingga keinginan terhadap jumlah anak terutama anak laki-laki cenderung tinggi.

Nilai anak merupakan aspek yang tidak kalah pentingnnya karena menyangkut motivasi untuk mempunyai jumlah anak banyak/sedikit dan nilai- nilai tentang anak itu sendiri. Pada masyarakat suku Bajo yang ada di desa Mola Utara dan Mola Selatan anak merupakan pembawa rezeki. Sehingga mereka masih meyakini bahwa banyak anak berarti banyak rezeki. Selain itu anak memiliki makna bahwa dengan jumlah anak yang lebih banyak, terutama bagi kaum laki-laki menunjukkan kepercayaan diri (keperkasaan) terutama memiliki anak laki-laki. Apabila tidak demikian, maka akan ada rasa minder atau kurang percaya diri terutama bagi yang tidak memiliki anak.
Di samping itu ada nilai kepemilikan dari orang tua terhadap anak. Orang tua merasa bahwa jika memiliki anak lak-laki berarti mereka memiliki sepanjang masa, sedangkan perempuan merasa memilikinya hanya sesaat. Orang tua merasa memiliki anak laki-laki sebelum kawin dan setelah kawin. Orang tua masih berani meminta tolong (berupa materi) kepada anak laki-laki karena menurut mereka yang bekerja adalah anak laki-laki. Sementara anak perempuan hanya memilikinya sebelum kawin namun setelah kawin, orang tua merasa bukan lagi milik mereka (milik suami). Orang tua tidak berani meminta tolong (materi) kepada anak perempuannya yang kawin karena yang bekerja adalah suaminya. Dengan demikian keinginan terhadap jumlah anak cenderung tinggi. Hal ini tentunya dapat mempengaruhi fertilitas.

Pola perkawinan yang terjadi pada suku Bajo setelah mendarat dan menjadi bagian dari orang kota (era perubahan) adalah sesama suku (endogami) dan antara suku (eksogami). Sesama suku (endogami) terjadi antara Bajo dengan bajo atau di sebut "sama vs sama" sedangkan antara etnis disebut "sama vs bagai". Mayoritas perkawinan antara suku (sama vs sama) biasa terjadi antara laki-laki diluar etnis Bajo (bagai) dan perempuan berasal dari suku Bajo.

Pola perkawinan sesama fertilitasnya cenderung tinggi. Hal tersebut disebabkan karena masih dominannya budaya suku Bajo mengenai nilai-nilai anak yang 
berlaku. Sementara perkawinan antara suku cenderung menurunkan fertilitas. Hal tersebut disebabkan oleh dominasi suami dalam pengambilan keputusan tentang anak. Sehingga nilai-nilai tentang anak yang belaku dalam suku Bajo sudah mulai berubah. Mereka lebih memandang dari sisi "cost" karena mereka memikirkan kelanjutan masa depan anak terutama dari segi pendidikan. Dengan demikian dapat dikatakan bahwa percampuran dua budaya yang berbeda bisa menurunkan fetilitas.

Sistem kekerabatan pada masyarakat suku Bajo merupakan sistem kekerabatan dekat dan kekerabatan jauh. Secara umum nampak bahwa pada masyarakat suku Bajo, ide tentang "keluarga besar" nampaknya masih kuat. Banyak keluarga yang dekat dan jauh masih dianggap menguntungkan.

Norma keluarga besar masih merupakan pilihan dibandingkan dengan norma "keluarga kecil". Mereka masih menganggap bahwa dengan banyak anggota keluarga sistem kekerabatan mereka akan semakin erat dan saling membutuhkan.

Hal tersebut sebagaimana yang dikatakan oleh Singarimbun (1978) bahwa penilaian yang tinggi kepada "keluarga besar" mencerminkan kenyataan berlakunya "loyalitas primodial" yakni loyalitas kepada keluarga, suku dan golongan. Dengan demikian jika yang berlaku adalah "nilai keluarga besar" maka secara otomatis tingkat fertilitas akan semakin tinggi.

\section{Penutup}

\section{Simpulan}

Berdasarkan hasil dan
pembahasan tersebut dapat
disimpulkan:

- perencanaan keluarga yang ada pada pasangan suami-istri suku Bajo di desa Mola Utara dan Mola Selatan adalah semata-mata masih berdasarkan atas keuntungan dari keluarga besar, sehingga yang berlaku adalah nilai keluarga besar,

- aspek- aspek yang menentukan perencanaan keluarga suku Bajo di era perubahan adalah aspek sosial-ekonomi, demografi dan budaya,

- kondisi tersebut (1 dan 2) berimplikasi pada penggunaan alat kontrasepsi KB yang mana mayoritas wanita usia subur (1549) tahun mayoritas tidak menggunakan alat kontrasepsi KB.

Dengan demikian, mengakibatkan jumlah Anak Lahir Hidup (ALH) dan Anak Masih Hidup (AMH) pada wanita usia subur (1549) tahun lebih tinggi, yaitu di daerah penelitian menunjukkan rata-rata Anak Lahir Hidup (ALH) adalah (3-4) orang dan Anak Masih hidup adalah 2,9 atau 3 orang.

\section{Rekomendasi}

Suku Bajo sebagai masyarakat dengan karasteristik budaya yang sedikit tertutup harus mendapatkan perhatian khusus terutama pada pengalokasian sarana dan prasaran pendidikan mulai dari pendidikan dasar sampai 
ke pendidikan tingkat menengah atas dan fasiitas kesehatan yang memadai di tengah perkampungan Mola. Dengan demikian tidak ada lagi alasan atas keterbatasan akan akses pendidikan dan kesehatan terutama dari segi jangkauan.

Perlu ada sosialisasi yang intens dengan masyarakat, terutama dari petugas KB yang ada di kabupaten/kota agar tidak terjadi pemaknaan yang salah terhadap alat kontrasepsi KB. Para petugas KB yang ada harus mengkader masyarakat setempat agar dalam melakukan sosialisasi atau pendekatan terutama masyarakat Bajo yang sedikit tertutup bisa lebih cepat diterima.

Perlu ada kebijakan yang komprehensif untuk mengendalikan penduduk suku Bajo yang ada di desa Mola Utara dan Mola Selatan. Mengingat suku Bajo Mola menempati wilayah konservasi Taman Nasional Wakatobi. Sehingga tidak menutup kemungkinan, dengan laju pertumbuhan yang tinggi akan berdampak pada lingkungan. Hal ini sangat terkait dengan aktifitas mereka yang mengeksploitasi batu karang laut bahkan terumbu karang untuk permukiman mereka.

\section{Daftar Pustaka}

Anonim. 2010. Etnografi Suku Bajo. STAIN Salatiga Press. Salatiga. --. 2011. Orang Bajo Di Tengah Perubahan. Ombak: Yogyakarta.

$\begin{array}{crr}\text { Basroni \& } & \text { Suwandi, } & 2008 . \\ \text { Memahami } & \text { Penelitian } \\ \text { Kualitatif. } & \text { Rineke } & \text { Cipta: } \\ \text { Jakarta. } & & \end{array}$

Becker, 1995. An Economic Analysis of Fertility. Dalam The Essence of B.E.C.K.E.R. Ramon Febrero dan Pedro S. Schwartz. Hoover Institution Press. Stanford University, Stanford, California.

Badan Pusat Statistik. 2010, Sulawesi Tenggara Dalam Angka. BPS Propinsi Sulawesi Tenggara.

Badan Pusat Statistik. 2010. Wakatobi Dalam Angka. BPS Kabupaten Wakatobi.

Mahmud, 1980. Pentingnya Pembinaan Pendidikan Islam Bagi Masyarakat Desa Mola Kecamatan Wangi-Wangi. Universitas Alauddin : Baubau. Mantra, I.B. 2000. Demografi Umum. Pustaka Pelajar Yogyakarta. Yogyakarta.

Singarimbun, M. 1978. Faktor-Faktor Sosial dan Kebudayaan yang Mempengaruhi Fertilitas dan Mortalitas. Lembaga Kependudukan Universitas Gadjah Mada: Yogyakarta.

Suandi. 2010. Status Sosial Ekonomi dan Fertilitas (A Latent Variable Approach). Jurnal Piramida, Vol 6 No 1 Juli 2010. 